\title{
OPEN
}

Published online: 23 January 2020

\section{Author Correction: Brain targeting of 9c,11t-Conjugated Linoleic Acid, a natural calpain inhibitor, preserves memory and reduces $A \beta$ and P25 accumulation in 5XFAD mice}

\section{Orli Binyamin, Keren Nitzan, Kati Frid, Yael Ungar, Hanna Rosenmann \& Ruth Gabizon}

Correction to: Scientific Reports https://doi.org/10.1038/s41598-019-54971-9, published online 05 December 2019

The original version of this Article contained an error in Affiliation 2, which was incorrectly given as 'Chemistry laboratory, Milouda \& Migal Laboratories, Meriux Nutrisciences, Milu’ot South Industrial Zone, Akko, Israel'. The correct affiliation is listed below:

Chemistry laboratory, Milouda \& Migal Laboratories, Merieux Nutrisciences, Milu’ot South Industrial Zone, Akko, Israel.

In addition, the Author Contributions section in the original version of this Article was incorrect.

"O.B. performed experiments, treated the mice and performed immunohistochemistry and western blot studies and edited the manuscript. K.N. performed the Behavioral tests and relevant statistics. K.F. assisted when needed. Y.U. performed the pharmacokinetic studies. H.R. donated the 5XFAD line and counsel about the experiments. R.G. conceived experiments and wrote the manuscript. All authors read and approved the final manuscript."

now reads:

"O.B. performed experiments, treated the mice and performed immunohistochemistry and western blot studies and edited the manuscript. K.N. performed the Behavioral tests and relevant statistics. K.F. assisted when needed. Y.U. performed the pharmacokinetic studies. H.R. counsel about the behavioral experiments. R.G. conceived experiments and wrote the manuscript. All authors read and approved the final manuscript."

These errors have now been corrected in the HTML and PDF versions of the Article. 
(c) (i) Open Access This article is licensed under a Creative Commons Attribution 4.0 International License, which permits use, sharing, adaptation, distribution and reproduction in any medium or format, as long as you give appropriate credit to the original author(s) and the source, provide a link to the Creative Commons license, and indicate if changes were made. The images or other third party material in this article are included in the article's Creative Commons license, unless indicated otherwise in a credit line to the material. If material is not included in the article's Creative Commons license and your intended use is not permitted by statutory regulation or exceeds the permitted use, you will need to obtain permission directly from the copyright holder. To view a copy of this license, visit http://creativecommons.org/licenses/by/4.0/.

(C) The Author(s) 2020 